\title{
The Impact of Sport Sponsorship on Brand Value: Evidence from Algeria
}

\author{
Sid Ahmed Hadj Aissa \\ Blida 2 University, Blida, Postal Code 09015, Algeria \\ E-mail: s.hadj_aissa@live.fr
}

Ali Matar (Corresponding author)

Banking and Financial Science Department, Jadara university

Irbid, P.O. 733, Postal Code 21110, Jordan

E-mail: kenoali87@yahoo.com

Received: December 22, 2015 Accepted: January 10, 2016

doi:10.5296/ber.v6i1.9453 URL: http://dx.doi.org/10.5296/ber.v6i1.9453

\begin{abstract}
The study aims to explore the influential relationship between sports sponsorship and brand value dimensions (consumer trends, brand image and loyalty to the mark). Non-random sample is used and 345 single surveys have been distributed in Algeria. Non-random sampling is any other kind of sampling. Such methods are often used for speed and convenience, and also they do not require a sampling frame. The result suggested that there is a significant impact of sports sponsors on consumer trends (cognitive component, emotional component, component behavior). Besides, there is another impact of sports sponsors towards the brand image of sporting event. The study also detected the impact of sports sponsors on the brand loyalty for sponsors of sporting event. On the other hand, with respect to the differences between sample answers, the results suggested that there are differences in the trends sample about the impact of sports sponsors brand value dimensions (consumer attitudes towards the brand, brand image, loyalty to the mark) depending on the demographic and functional variables (age, sex, educational level, profession, trader type).In summary, the study recommended to activate the sports sponsorship process by various communication devices such as advertising and public relations.
\end{abstract}

Keywords: Sports marketing; Sports sponsorship; Brand; Consumer; Algeria. 


\section{Macrothink}

\section{Introduction}

Sponsorship in the field of sports is characterized by assemble nature, and it is not more complicated than any activities within the mixture promotion of institution, which contain many common marketing elements, while some joint marketing elements operate separate units such as a discount on entry tickets for the games or programs of public relations. The sponsorship used two elements or more of the marketing mix to provide the sponsor with connection, value, presentation in the media, and take advantage of the sponsorship opportunities to achieve its goals of communication with the target groups.

Therefore, the sports sponsorship in various forms processes a wide range of activities associated with communications designed to exploit the sports and marketing, including sending a set of messages to the target audience. However, sport sponsorship offering a kind sort of media agreement between two parties that has become commonly used in sports and economic institutions. The advertising licensing includes a range of rights that proved and acceptable to the whole world, sponsorship is usually refers to the acquisition of rights in order to make profits accrue to the sponsoring institution and on goods produced by the institution itself (Shalabi, 2005).

As a communication channel, the abundant advantages provided by watching sports events encourages the institutions to develop their traditional marketing methods and inject a mixture contacts linked to these events in order to take advantage of the marketing opportunities that offers by this events. Recently, the sponsorship institutions have been increased, where these institutions look at the importance of sponsor as a necessity marketing superiority of advertising and sales promotion ${ }^{2}$. In 2014, the spending of American institutions in this area showed an increase of 4.2 percent to about $\$ 20.6$ billion. Furthermore, the expectations indicate that with the end of the year 2015 it will reach to $\$ 21.4$ billion with an increase of $4.2 \%$ as shown in Figure 1.

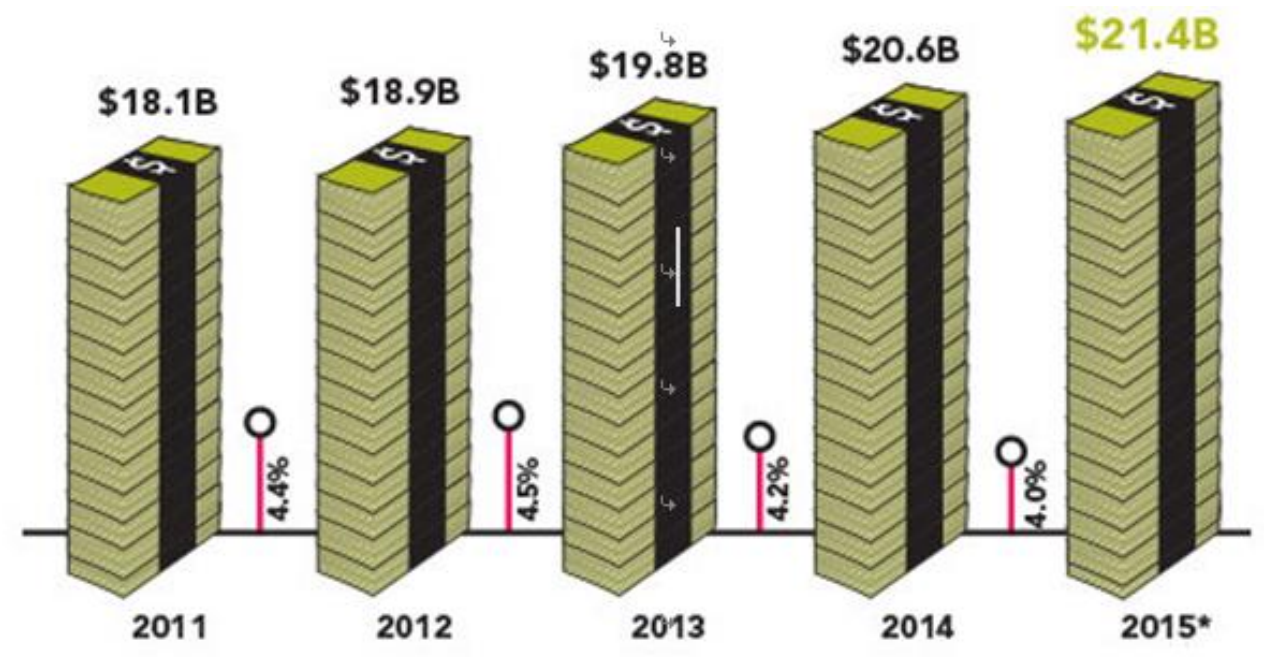

Figure 1. Total North American Sponsorship Spending 
The global institutions consider the sponsorship marketing as a necessity that outweighs the television commercials, which takes a few minutes to display, where it sponsored sports teams, sports facilities, professional sports events, festivals, and exhibitions. Nevertheless, the main goal of this sponsorship is to present their own brand for billions of followers.

The problem of the study stated that sports sponsorship is considered as the most important tool in sports marketing, which seeks to license the image of brands in the minds of consumers through various sponsored sporting events, especially those that attract the largest number of viewers. Generally, sports sponsorships defined as a commitment from an organization (the sponsoring institution) to finance or embrace a specific occasion with committed to all or part of the costs, to highlight its identity, its name, its brand and its image with a commitment to connect all of this sport, event, sports team or sports beneficiary of sponsorship.

In addition, the most sports sponsorship targets for dramatically brand, whether to improve its image or strengthening of reputation or increase its value, or even offered it for the new institutions. The study of the brand and the elements that influenced it enters in special studies in the process of marketing field. Thus, we must study the brand interaction with sports sponsorship in the consumer's mind, and the add value of sports sponsorship to the sponsor brand. Nonetheless, the sponsor brand becomes a strong sign in consumer's mind that heavily linked with the sponsorship event.

This study is lies in showing the value that sport sponsorship added for the brand, and extracted it from different variables like (consumer trends, brand image, brand loyalty or even demographic variables). On this basis, the problem of this study is stated as follows: "As a way of communication, to what extent the sport sponsorship can affect the value of the brand". The current study is attempts to answer the following questions:

- Is there any impact of sport sponsorship on the consumer trends (cognitive component, emotional component, behavioral component) toward the sponsor's brand for sporting event?

- Is there any impact of sport sponsorship on the image of the sport brand that sponsor the sporting event?

- Is there any impact of sport sponsorship on the loyalty for the sport brand that sponsor the sporting event?

To answer the previous questions, the study proposed the following three main hypotheses:

- There is no significant impact at the $0,05 \geq \alpha$ level of significance of sport sponsorship on consumer trends (cognitive component, emotional component, behavioral component) toward the sponsors brand for the sports event.

- There is no significant impact at the $0,05 \geq \alpha$ level of significance of sport sponsorship on the image of the sport brand that sponsor the sporting event.

- There is no significant impact at the $0,05 \geq \alpha$ level of significance of sport sponsorship on the loyalty for the sport brand that sponsor the sporting event. 
The rest of the paper is structured as follows: The next section explores the evolution of sports sponsorship expenditures in the world. Section 3 presents the literature review. Section 4 produces the methodology of the study. Section 5 proceeds with the results analysis. Section 6 examines the hypotheses testing. Finally the conclusion is reported in the last section 7 .

\section{The Evolution of Sports Sponsorship Expenditures in the World}

The past decade witnessed an increasing in the desire of economic institutions to support and encourage the sports competitions, places, although the soccer fields are for the most of the spending on this kind of sponsor due to different reasons such as:

- Large numbers of viewers football inside football stadiums (In America basketball courts) in particular.

- Effectiveness and the impact of the advertisement in the soccer courts.

However, to avoid the confusion between the concept of sport sponsorship and the rest of the constituent elements of the marketing communications mix, it became necessary to clearly define the concept of sponsor places for sports competitions, objectives and different intellectual entrances associated with them, in addition to the entrances to some theoretical value of the relevant brand.

The study showcases the evolution of sports sponsorship expenses on a global level with these expenses compared to the expenses of the other marketing communication techniques (Advertising and sales promotion), as well as highlight some of the concepts related to sports sponsorship and its importance.

Most of the previous studies defined the sport sponsorship as "the exchange relationship between the official sponsor and the beneficiary of this sponsor to track marketing communications link and the partnership between the two sides." Most studies have focused primarily on the objectives and motivations to invest in sponsor represented in that the objectives sought by the institutions in exchange for the right to promote brand awareness and enhance the brand image of these institutions (Cornwell, 2001).

Also, it is known as "a source of support funds, personnel, equipment used by institutions, whether directly or indirectly in sporting events and tournaments in order to achieve the company's goals and promote the brand (Sandler, 1989). While another study showed that sport sponsorship is the only arrangement of funding by the sponsors of the sport event businesses, whether it is cash or in kind in order to take advantage of the sporting event mainly for commercial gain and economic advantages (Tripodi, 2001). Consequently, the sports sponsorship is financial and substantial support or provision of services introduced by an institution or a person to get a direct benefit. The aim behind this process is the definition of the institution (by the taxpayer) conditions, their products or brand and reap the positive effects on the level of the image. At this institution is looking for a part or the whole polarization values of sport and funded by some of the cultural elements that surround this type of sport. It's also a contract between the taxpayer and the taxpayer shows the various duties imposed on both of them and some of the proposed solutions in case of dispute. 


\section{Macrothink Institute ${ }^{\mathrm{TM}}$}

Sports sponsorship has evolved considerably at the global level and that is an evidence of the realization of global economic prospects institutions of the importance of sport as a profitable market in the communication marketing capabilities for the development of institutions that make many of them flocking to spend sponsorship contracts with various clubs and events. The amounts that spent in the field of sports sponsorship have reached to levels exceeded all expectations in 2014, where global spending rate reached in the field of sports sponsorship institutions to $\$ 55$ billion after it was $\$ 48$ billion in 2011 and $\$ 44$ billion in 2009. Forecasts indicate that, by the end of 2015 it will bring the total spending to 57.5 billion dollars. This enormous development during these years is evidence of the effectiveness of this method in achieving the goals.

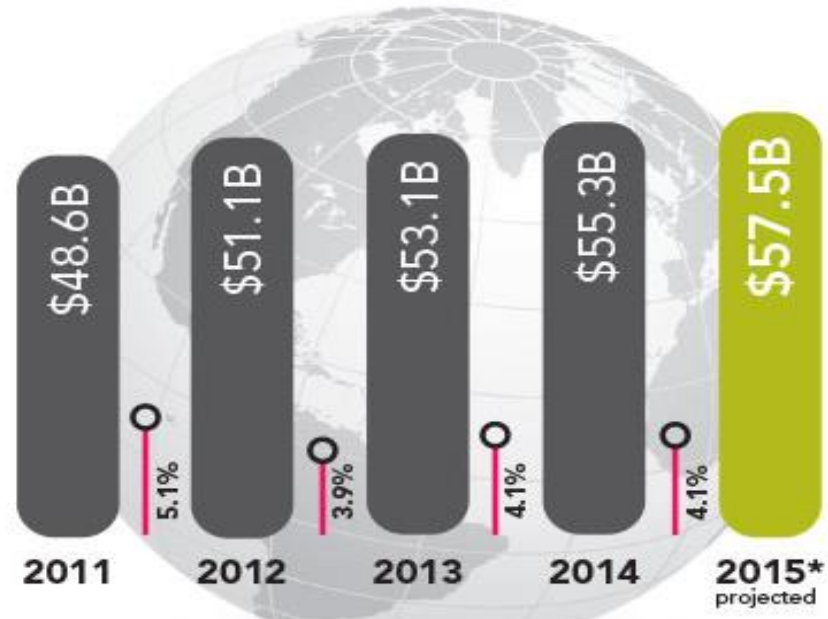

Figure 2. The total sports care costs in the world [2011-2015]

Source :http://www.sponsorship.com/iegsr/2015/01/06/New-Year-To-Be-One-Of-Growth-And-Challenges-for-Sp.aspx

Sports sponsorship expenses compared to the rest of the communications, marketing mix elements:

Figure 3 reveals that the global economic institution's expenses on sports sponsorship stay stable at the growth level of $4.1 \%$ for the years 2014 and 2015, according to projections, also it shows that the projections also indicate that, by the end of 2015 the advertising spending rates will increase to $4.9 \%$ from an estimated growth rate to $3.9 \%$. This recent rise in advertising expenses due to the increase of approximately $10 \%$ of the growth in advertising spending in China, as well as the strong spending, Brazil, Britain, Japan and India, it is expected that, by the end of the same year (2015) will reach sales promotion expenses to equal rates of growth with sports sponsorship. 


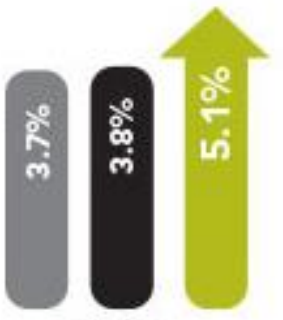

2012

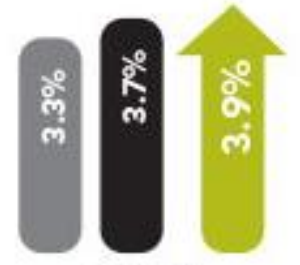

2013

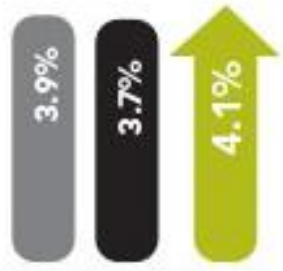

2014

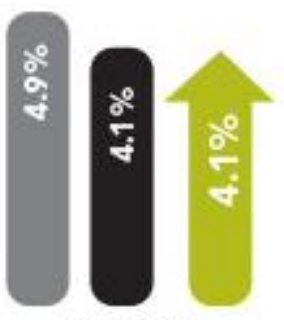

2015*

PROJECTED

\section{ADVERTISING}

MARKETING/PROMOTION

SPONSORSHIP

Figure 3. The annual growth rate of expenditures on sports sponsorship, advertising and sales promotion [2012 to 2015].

Source :http://www.sponsorship.com/iegsr/2015/01/06/New-Year-To-Be-One-Of-Growth-And-Challenges-for-Sp.aspx

Statistics in Table 1 show that with the exception of North America, the global spending in the field of sports sponsorship came to 34.7 billion dollars in 2014, and this figure is expected by expectations to reach $\$ 36.1$ billion by the end of 2015 . What should be noted here is that the economic situation in Europe should continue to keep the European region close to the planned growth rates, which is expected to grow care sector by $3.3 \%$ in 2015 . Despite of that low rate, it remains better than 2014 (2.1\%).The data also indicates that the Asia-Pacific region continued to give the crucial importance of care across almost all countries and incited to invest in it because of its great returns this confirms the spending rate (5.2\%) in 2015, rates of spending, this must continue to achieve a head start compared to the countries of Central and South America, even with the contributions of the agreement related to the care to the Olympics in 2016 in Rio de Janeiro.

Table 1. Global Sponsorship Spending By Region

\begin{tabular}{|lrrrrr}
\hline & $\begin{array}{l}2013 \\
\text { SPENDING }\end{array}$ & $\begin{array}{l}2014 \\
\text { SPENDING }\end{array}$ & $\begin{array}{l}\text { INCREASE } \\
\text { FROM 2014 }\end{array}$ & $\begin{array}{l}2015 \\
\text { SPENDING } \\
\text { (PROJECILD) }\end{array}$ & $\begin{array}{l}\text { INCREASE } \\
\text { FROM 2015 } \\
\text { (PROIECIED) }\end{array}$ \\
\hline EUROPE & $\$ 14.5$ BILLION & $\$ 14.8$ BILLION & $2.1 \%$ & $\$ 15.3$ BILLION & $3.3 \%$ \\
\hline ASIA PACIFIC & $\$ 12.6$ BILLION & $\$ 13.3$ BILLION & $5.6 \%$ & $\$ 14$ BILLION & $5.2 \%$ \\
\hline CENTRAL/SOUTH AMERICA & $\$ 4$ BILLION & $\$ 4.2$ BILLION & $5 \%$ & $\$ 4.3$ BILLION & $4.8 \%$ \\
\hline ALL OTHER COUNTRIES & $\$ 2.3$ BILLION & $\$ 2.4$ BILLION & $4.3 \%$ & $\$ 2.5$ BILLION & $4.2 \%$ \\
\hline
\end{tabular}

Source : http://www.sponsorship.com/About-IEG/Press-Room/IEG-Projects-North-American-Sponsorship-Spending-t.aspx

Usually the customer experience with the product is formed through his dealings with the technical and functional characteristic of the package of this product and expressed at the price reflects the quality of these properties and excellence in the satisfaction of consumer needs. However, the importance of the brand stands out as an identifier and characteristic of the product or of the institution produced, also as an adjunct to the customer in determining the expectations of the product and in its evaluation of current, past, and future experience 
with this product. Therefore, the brand is considered as an influential factor in the decision of purchasing for the consumer, and in appreciation of the extent of the risk associated with the purchase of the product and consumption. Thus, the brand cannot be seen as a brand or name only, but as a concept that includes several dimensions linked to the consumer experience with this product.

\section{Literature Review}

McDaniel (1999) tested the notion that consumers possess schemas that influence their reactions to advertising leveraging sport sponsorships. The research utilizes a $3 \times 2 \times 2$ factorial design, where three variations of sport sponsorship, print ads and two different magazine covers (sport and non-sport) are used to test the influence of brand/event matchups and advertising placement on intermediate measures of advertising effectiveness. To match up and media vehicle effects, differential response by gender is also examined. Three hypotheses are tested based on research from the literature on sponsorship, matchup effects, and advertising schemas. MANOVA results provide partial support for all three hypotheses, as matchup and media vehicle manipulations were found to significantly impact Aad. Moreover, females are found to report significantly higher Aad and Pi than did males in this study. The advertising schema framework is used to discuss the research findings.

Irwin et al. (2003) examined the attitudes, beliefs, and purchase intentions of consumers exposed to a firm's sponsorship of a sporting event associated with a non-profit organization. A survey instrument was developed by a panel of experts, protested, revised, and completed by 442 event spectators, in Memphis, Tennessee, USA. Results suggested consumers' attitudes, beliefs, and purchase intentions toward the sponsoring company were positively impacted by the firm's involvement with cause-related marketing.

Kim (2010) investigated the relationship between sports-related event sponsorship and stock market valuation and identifies factors that influence the financial rewards of sponsorship using World Cup and PGA tour sponsorship data. Event study results showed that sponsorship of the World Cup and PGA is positively related to abnormal stock returns for sponsors, but not every sponsor enjoys significantly positive cumulative abnormal returns. Regression analysis indicated that unexpectedly brand equity and U.S. country of origin is negatively associated with financial performance. Furthermore, U.S. sponsors with top brand value boost their abnormal stock return. Product fit enhances short-term financial performance, but the significant impact of the event type of financial outcome was not observed.

Donlan (2014) examined the contribution of live sponsorship to consumer-based brand equity .The study adopted a quantitative survey by employing self-administered questionnaires at two UK sporting events. The results suggested that sponsorship can be an appropriate vehicle through which to build consumer-based brand equity. Besides, the results indicated that the most successful sponsorship displayed marked contributions to building brand associations, perceived quality and brand loyalty.

Reiser et al. (2012) analyzed the effect of sponsorship announcements on the firm value of 
sponsoring firms by investigating whether sponsorship announcements have an influence on abnormal returns on share prices. The results of the event study provide evidence that sport sponsorship announcements are positively impacting stock returns, but this impact differs among sports and regions. The regression results suggested that abnormal returns are significantly higher for sponsorships on brand level, smaller firms, and deals with national reach.

Quester and Plewa (2008) measured the influence of emotions on attitude toward sponsors on sponsorship effectiveness. The study addressed this gap by proposing a causal model, incorporating affective variables (emotional intensity and valence) within an emotional process (transfer of affect). Data from a pilot study $(n=143)$, undertaken during the Australian Open 2008, confirms the centrality of emotions in the sponsorship persuasion process, for two of the four studied brands.

Utterström (2007) provided a better understanding of sport sponsorship as a marketing communication tool in Swedish companies. A qualitative, case study methodology was used, using interviews and documentation of two Swedish companies within the same field of business. The result indicated that several objectives of sport sponsorship are commonly used, and the objectives may be either constant or inconstant depending on sponsored unit. The most frequently used objectives of sport sponsorship are the corporate related objectives, such as, employee relations, client entertainment, and corporate image.

Pijkeren (2010) explored the network behind the sport sponsorship is highly valuable for sponsors. Due to the sponsorship network centrality of sponsors increases. Relationship intensity is highly dependent on the participation of all parties. Striking results are found when analyzing the amount and type of contents exchanged. For sponsors the amount of contents exchanged with others increases, whereas the type of contents exchanged changes. Sponsorship networks facilitate the exchange of information, as well as the exchange of goods and services. The exchange of information might be of more value because it may contain information about a particular market, new product or a more efficient product process. Underexposed for a long time, the network opportunity behind sponsorships now seems to gain interest from both network scientists and practitioners. As such, as well as providing a conceptual extension to the sponsorship literature, the study also offers a route for more empirical analyses of other sponsorship networks.

Weissman (2014) assessed perception, brand loyalty, receptiveness, and recollection of fans of the Lake County Captains minor league baseball team of the companies that sponsor the team. Two hundred and ninety-two participants (163 females and 126 males) completed this study. Participants completed the questionnaire, which included a demographics section, a question about team allegiance, and two Likert scales testing participants' perception and knowledge about the sponsors of the team in relation to: Sponsorship, Perception, Brand Loyalty, Receptiveness, and Sponsorship Recollection. One-way MANOVAs were used to assess the impact of allegiance, gender, education, and income on the spectators' opinions of the sponsors, brand loyalty, perception, and receptiveness. The results showed that the majority $(76 \%)$ of fans either follow the Lake County Captains sometimes or consistently 
follow the Lake County Captains. Significant differences were found in opinions of the sponsors, brand loyalty towards sponsors, opinions of perception, receptiveness towards sponsors amongst fan allegiance. Fans with higher levels of allegiance rated items significantly higher than those with lower allegiance. Significant differences were also found in opinions of the sponsors, brand loyalty towards sponsors, and receptiveness towards sponsors amongst education of fans. Fans with a higher education rated items higher than those with lower levels of education.

Biscaia et al. (2013) examined the relationship among the behavior, loyalty, attitude, sponsorship awareness, attitude toward the sponsor and purchase intention of the both actual sponsor for the team Sport Lisboa e Befica (SLB) in the Portuguese soccer league. Data were collected by a fan of the soccer team. The data were used conform factor analysis (CFA) to testing the significance of the hypothesis models. There are finding the difference significant among the relationship of the both sponsor.

\section{Methodology of the Study}

The study adopted descriptive, analytical and practical methodology. In terms of descriptive, it conducted a one-stage survey and look at the literature reviews to develop the basis and premise underlying theoretical framework, besides exploring the most important previous studies that represented vital tributary and valuable component of knowledge axes. In terms of analytical part, it has been conducting a comprehensive exploratory survey, and analyzed all the data collected by answering questionnaires and using appropriate statistical methods according to the study axes. The basic factors that must be identified before starting the study is the research population, which "is a finished or unfinished of pre-selected item group, collects property or several common characteristics that distinguish them from other elements that are selected for research and investigation" .

Thus, the study population is made up of all the variables that make up the problem of the study, and their number varies according to study purpose and the degree of accuracy. For this study, the population of the study consists of a group of consumers for different customers mobile phone in Algeria, and who are interested in sports due to the huge size of the population and the difficulty of applying comprehensive incarcerations a result of several

factors such as, lack of time, the high cost, therefore we chose to do an inspection.

In this study, we relied on the sample is not a random spin-off "sample coincidence", and this type of sample is chosen by chance as a certain public opinion newspaper inquiring about a particular issue or candidate, and often this type of sampling is representative of a community study, this kind of sample is used in survey initial exploratory studies. The researchers adopted as we mentioned on the sampling method, where the study sample size was estimated under the following assumptions:

- Standard error limits of $5 \%$.

- Population size more than 40,000.

- The researchers chose (95\%) level of significance. 


\section{Macrothink}

The sample size reached (381) individuals according to identifying the sample size program as follows:

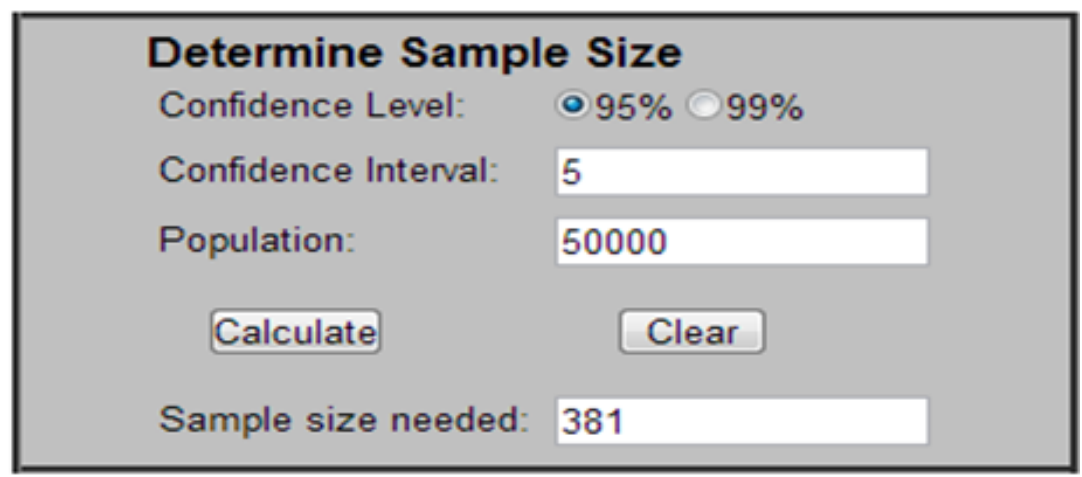

Source :http://www.surveysystem.com

The researchers have distributed the questionnaire to a sample size of 381 individuals using personal interviews with them, as well as the reliance on communications technology developed 130 lists of the survey in groups on social networks (Facebook) in the distribution and collection of questionnaire process, which enabled us to get the response rate in the full study sample $90.55 \%$ of the identification of any 345 (List survey are valid for analysis).

To achieve the objectives of the study and analyze the collected data, we relied on a set of statistical methods and software applications using this statistical package in the field of social sciences, known commercially as Statistical Package for Social Science (SPSS Win Version 20). Descriptive statistics and analytical methods were used to answer the study questions and test the validity of hypotheses, namely:

- Arithmetic average: in order to know the study trends toward each paragraph that helps in the order of paragraphs to the highest weighted average.

- Standard Deviation: in order to identify the extent of deviation members study the responses of nearly every paragraph, and also noted that the standard deviation also shows the dispersion in individual responses of the study, The closer the value of zero, it means focusing answers and lack of dispersion, but if the value is equal to one or the largest, it means not to focus answers and dispersion.

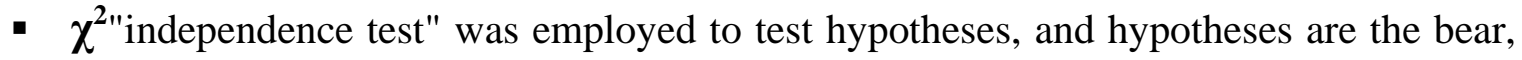
the null hypothesis and accept the hypothesis. If $\chi^{2}$ was greater than the level of significance is chosen, it shows the independence of the two variables for each and no one affects the other, and vice versa.

- The Reliability coefficient (Cronbach's alpha): to make sure the internal consistency of the phrases survey, where this parameter takes a value between zero and one, and closer than the one it means greater stability for the study.

Before the survey, it was also necessary to test the stability of the survey, which means the 
stability of scale and lack of contradiction with itself, that means the survey will give the same results as a possible equal to the parameter value if it is re-distributed more than once under the same circumstances and conditions, which means that there stability in the results of the questionnaire and not changed significantly in the case of re-distributed to the members of the sample several times. We have to verify the stability of the questionnaire by the alpha coefficient of Cronbach's alpha, this question with respect to the stairs, and the results were as follows:

Table 2. Cronbach's Alpha test results to measure the stability of the survey

\begin{tabular}{|c|c|}
\hline Question & Cronbach's Alpha coefficient \\
\hline All Questions & 0.739 \\
\hline
\end{tabular}

Source: prepared by researchers based on the results of the statistical analysis

The result reveals that Cronbach's alpha coefficient is greater than the range of (0.7-0.8) indicates that the study is well consistently. The high degree of internal consistency of the variables confirms the stability of the questionnaire, and the root of the Cronbach's alpha coefficient is obtained on the credibility of the value of $85.96 \%$ confirms the validity and reliability of the study survey.

The definition of brand value has been presented through two points of view, the first point is marketing and the second is financial point of view, the following is a brief review of each of them:

Brand values from the point of view of marketing: Many researchers provide definitions of various brand value and the most important of these definitions:

- "Is a group of assets and liabilities associated with the slogan and the name of the brand and that add or reduce the value provided by good or service to the organization or to the consumers of this institution, or both (Aaker, 1996)."

- "Is the increase in the perceived benefit and the attractiveness that it places the brand on a product, and it is a consumer awareness of the overall excellence of a product that the brand compared with other trademarks (Lassar, 1995)."

" -Is the marketing effects that can be attributed to a single brand", and when the product marketing of certain outcomes resulting from its brand achieved and these outputs could not have occurred if this product does not carry that brand (Keller, 1993)."

Brand value from the financial point of view:

- "Is an additional cash flow arising from the brand name products compared with products that do not carry trademarks (Simon, 1993)."

\section{Results Analysis}

To see trends in the study sample vocabulary towards the sponsored trademark, weighted averages were calculated as well as the standard deviations of the study sample answers to the independent variable axes phrases. It evidenced by the results of the study sample 
vocabulary about the cognitive component as the following:

- Neutral direction toward their interest towards the sponsor brand of the sport event.

- Agree (approaching to strongly agreeing) towards identifying the sponsor brand through the slogans on the players T-shirts.

- Agreeing towards identifying the sponsor brand through the slogans on the stadium billboards.

- Agreeing towards identifying the sponsor brand through the slogans on the match tickets.

Generally, the study sample expressed their approval with respect to identify the sponsor sign of the sport event (aggregate weighted average M3.8014 = and standard deviation $\delta=0.800$ ), reflecting the perception of the population in the study sample of the activity of the sponsor in the sports field.

Table 3. Results of the cognitive component of statistical analysis

\begin{tabular}{|l|c|c|c|c|}
\hline \multicolumn{1}{|c|}{ Status } & $\begin{array}{c}\text { Weighted } \\
\text { Average }\end{array}$ & $\begin{array}{c}\text { Standard } \\
\text { Deviation }\end{array}$ & Order & Trend \\
\hline $\begin{array}{l}\text { Particularly interested in the sponsor brand of the sport } \\
\text { events }\end{array}$ & 2,9565 & 1,05977 & 4 & Neutral \\
\hline $\begin{array}{l}\text { Identifying the sponsor brand through the slogans on the } \\
\text { players T-shirts. }\end{array}$ & 4,3159 & 0,61816 & 1 & Agree \\
\hline $\begin{array}{l}\text { Identifying the sponsor brand through the slogans on the } \\
\text { stadium billboards. }\end{array}$ & 4,2319 & 0,63923 & 2 & Agree \\
\hline $\begin{array}{l}\text { Identifying the sponsor brand through the slogans on the } \\
\text { Match tickets. }\end{array}$ & 3,7014 & 0,88306 & 3 & Agree \\
\hline \multicolumn{1}{|c|}{ Total } & 3.80 & 0.800 & - & Agree \\
\hline
\end{tabular}

Source: prepared by researchers depending on the results of the statistical analysis.

The results suggest an evidence of neutral trends in the items of the emotional component sample toward the sign of the sponsor of the sport event, most answers respondents were nearly neutral (aggregate weighted average $\mathbf{M}=\mathbf{3} .120$ and standard deviation $\boldsymbol{\delta}=0.9784$ ), on the grounds that the passion does not have a significant relationship with the sport.

Table 4. Results of the emotional component statistical analysis

\begin{tabular}{|l|c|c|c|c|}
\hline \multicolumn{1}{|c|}{ Status } & $\begin{array}{c}\text { Weighted } \\
\text { Average }\end{array}$ & $\begin{array}{c}\text { Standard } \\
\text { Deviation }\end{array}$ & Order & Trend \\
\hline $\begin{array}{l}\text { Sponsor of the sporting event attract me to know its } \\
\text { services }\end{array}$ & 3,2609 & 0,98907 & 2 & Neutral \\
\hline $\begin{array}{l}\text { Sponsor of the sporting event imparts aesthetic overall } \\
\text { appearance for stadiums }\end{array}$ & 3,7188 & 0,85543 & 1 & Agree \\
\hline $\begin{array}{l}\text { I already changed my mind about a brand after its } \\
\text { sports sponsorship }\end{array}$ & 2,7420 & 1,00296 & 4 & Neutral \\
\hline
\end{tabular}




\begin{tabular}{|c|c|c|c|c|}
\hline $\begin{array}{l}\text { I trust more in the brand that sponsored the sporting } \\
\text { events }\end{array}$ & 2,7594 & 1,06617 & 3 & Neutral \\
\hline Total & 3.1202 & 0.9784 & - & Neutral \\
\hline
\end{tabular}

Source: prepared by researchers depending on the results of the statistical analysis

The result illustrates the differences in the answers in trends and opinions of a sample study vocabulary about the behavioral component as follows:

-Neutral about their search for the various offers made by the sponsor of the event.

- Agree to deal with the sponsor's brand of the sporting event rather than their competitors.

Generally, the study sample is neutral about their awareness of the component behavior toward the mark for the sponsor of the sport event (aggregate weighted average $\mathbf{M =}$ 3.0345and standard deviation $\boldsymbol{\delta}=0.9553$ ).

Table 5. The results of the statistical analysis of behavioral component

\begin{tabular}{|l|c|c|c|c|}
\hline \multicolumn{1}{|c|}{ Status } & $\begin{array}{c}\text { Weighted } \\
\text { Average }\end{array}$ & $\begin{array}{c}\text { Standard } \\
\text { Deviation }\end{array}$ & Order & Trend \\
\hline $\begin{array}{l}\text { I search for the various offers made by the sponsor of the } \\
\text { event }\end{array}$ & 2,8319 & 1,09471 & 2 & Neutral \\
\hline $\begin{array}{l}\text { I prefer to deal with the sponsor's brand of the sporting } \\
\text { event rather than their competitors }\end{array}$ & 2,8464 & 1,03550 & 1 & Agree \\
\hline $\begin{array}{l}\text { I will ask via internet to be a member of the sporting } \\
\text { event sponsor online club }\end{array}$ & 2,4000 & 0,91308 & 4 & Neutral \\
\hline $\begin{array}{l}\text { My consumption of the sponsors' products does not } \\
\text { relate to their sporting event }\end{array}$ & 4,0435 & 0,77824 & 3 & Neutral \\
\hline \multicolumn{1}{|c|}{ Total } & 3.0345 & 0.95530 & - & Neutral \\
\hline
\end{tabular}

Source: prepared by researchers depending on the results of the statistical analysis

The answers in this element have been collected about the brand image to determine the degree of approval of each phrase of the theme phrases, and the results were as follows:

It evidenced by the results of the descriptive study that the views of a sample study vocabulary have revealed their consent and dramatically and all statements in regards to the brand image sponsorship weighted average correlation $\mathbf{M}=3,6878$.

Table 6 . The results of the statistical analysis of brand image

\begin{tabular}{|l|c|c|c|c|}
\hline \multicolumn{1}{|c|}{ Status } & $\begin{array}{c}\text { Weighted } \\
\text { Average }\end{array}$ & $\begin{array}{c}\text { Standard } \\
\text { Deviation }\end{array}$ & Order & Trend \\
\hline $\begin{array}{l}\text { The sponsor of the sport event helps to improve the sport } \\
\text { system }\end{array}$ & 3,9594 & 0,77278 & 5 & Agree \\
\hline $\begin{array}{l}\text { Sports sponsorship contributes to the success the brand } \\
\text { for the sport event sponsor }\end{array}$ & 4,1826 & 0,67233 & 1 & Agree \\
\hline $\begin{array}{l}\text { Sponsor of the sport event raises the level of their brand } \\
\text { goodwill }\end{array}$ & 4,1565 & 0,54332 & 2 & Agree \\
\hline
\end{tabular}




\begin{tabular}{|l|c|c|c|c|}
\hline $\begin{array}{l}\text { Sponsor of the sport event contributes to increase the } \\
\text { media impact }\end{array}$ & 4,0203 & 0,67956 & 4 & Agree \\
\hline $\begin{array}{l}\text { Sponsor of the sport event contributes to increase the } \\
\text { budget of sport clubs and committees }\end{array}$ & 4,1536 & 0,66660 & 3 & Agree \\
\hline $\begin{array}{l}\text { Usually I link the image of the sponsor brand with the } \\
\text { his sponsored sport event }\end{array}$ & 3,3565 & 0,87794 & 6 & Agree \\
\hline $\begin{array}{l}\text { When sport event got loss or scandal, sponsor brand will } \\
\text { affected by this bad image }\end{array}$ & 1,9855 & 0,96889 & 7 & Disagree \\
\hline \multicolumn{1}{|c|}{ Total } & 3,6878 & 0,33874 & - & Agree \\
\hline
\end{tabular}

Source: prepared by researchers depending on the results of the statistical analysis

In this section the study sample answers have been collected and analysis about loyalty to the brand through sports sponsorship phrases individuals determine the degree of approval of each phrase of the theme phrases, and the results were as follows:

Table 7. Results of the statistical analysis of brand loyalty

\begin{tabular}{|l|c|c|c|c|}
\hline \multicolumn{1}{|c|}{ Status } & $\begin{array}{c}\text { Weighted } \\
\text { Average }\end{array}$ & $\begin{array}{c}\text { Standard } \\
\text { Deviation }\end{array}$ & Order & Trend \\
\hline $\begin{array}{l}\text { I will affirmatively talk about the brand of the sponsor of } \\
\text { sport event }\end{array}$ & 3,0493 & 0,96171 & 3 & Neutral \\
\hline $\begin{array}{l}\text { I have strong confidence in dealing with the services of } \\
\text { the sponsor of the sports events }\end{array}$ & 2,9420 & 0,91315 & 4 & Neutral \\
\hline $\begin{array}{l}\text { I have perfect satisfaction about the brand of the sponsor } \\
\text { of the sport event }\end{array}$ & 3,0870 & 0,94529 & 2 & Neutral \\
\hline $\begin{array}{l}\text { I am looking for the product of the institutions that } \\
\text { sponsored the sport events }\end{array}$ & 2,8000 & 1,00753 & 5 & Neutral \\
\hline $\begin{array}{l}\text { I am trying to solve the problems that face me in my } \\
\text { dealings with the sponsor of the sport events }\end{array}$ & 3,6986 & 0,85019 & 1 & Agree \\
\hline \multicolumn{1}{|c|}{ Total } & $\mathbf{3 , 1 1 5 4}$ & $\mathbf{0 , 5 7 2 8 6}$ & - & Neutral \\
\hline
\end{tabular}

Source: prepared by researchers depending on the results of the statistical analysis

Evidenced by the results of the descriptive study that the views of the study sample vocabulary have revealed that they are neutral in terms of their opinions about their loyalty to the sponsor brand of the sport event, this is what shows weak importance provided by consumers in the sign of sponsors, Most of them believe that their consumption loyalty to the sponsor sign is not necessarily significant with sport sponsorship that carried out by the institution, but they agree to solve the problems that face them in their dealings with the sponsor of the sport event.

\section{Hypothesis Testing}

In this section we will test the hypotheses of the study, which was represented by the three hypotheses were distributed to the three requirements, the use of statistical methods is 


\section{Ml Macrothink}

Business and Economic Research

ISSN 2162-4860

2016, Vol. 6, No. 1

mentioned in the first part, and in particular on the square of independence "chi-square" $\chi^{2}$ in this section.

Test the first hypothesis:" There is no significant impact at the $0,05 \geq \alpha$ level of significance of sport sponsorship on consumer trends (cognitive component, emotional component, and behavioral component) toward the sponsor's brand for the sports event".

To test the first hypothesis, we conduct tests of $\chi^{2}$ as follows:

- If the value of $\chi^{2}$ is greater than the value of the significant level at 0.05 , in this case," based on the "chi-squared of independence", it can be said that there is sufficient evidence to accept the null hypothesis test value, and therefore, it can be said that the two variables are independent and there is no significant impact between them.

- If the value of $\chi^{2}$ is smaller than the value of the significant level at 0.05 , in this case," based on the "chi-squared of independence", it can be said that there is sufficient evidence to reject the null hypothesis test value, and therefore, it can be said that the two variables are dependent and there is significant impact between them.

Table (08) reveals that the values of the explanatory dimensions for all functions are significant at the level $0,05 \geq$. Thus, we reject the null hypothesis and accept the alternative hypothesis; there is a significant impact of sport sponsorship on consumer trends (cognitive component, emotional component, and behavioral component) toward the sponsor's brand for the sports event.

Table 8 . The results of $\chi 2$ test of the first hypothesis

\begin{tabular}{|c|c|c|c|}
\hline Status & $\chi^{2}$ & P-value & Accept+/Reject- \\
\hline Particularly interested in the sponsor brand of the sport events & $115,884^{\mathrm{a}}$ & 0,000 & + \\
\hline Particularly interested in the sponsor brand of the sport events & $472,203^{\mathrm{a}}$ & 0,000 & + \\
\hline $\begin{array}{l}\text { Identifying the sponsor brand through the slogans on the players } \\
\text { T-shirts. }\end{array}$ & $358,362^{b}$ & 0,000 & + \\
\hline $\begin{array}{l}\text { Identifying the sponsor brand through the slogans on the stadium } \\
\text { billboards. }\end{array}$ & $266,493^{\mathrm{a}}$ & 0,000 & + \\
\hline Identifying the sponsor brand through the slogans on the Match tickets. & $204,638^{\mathrm{a}}$ & 0,000 & + \\
\hline Sponsor of the sporting event attract me to know its services & $408,116^{\mathrm{a}}$ & 0,000 & + \\
\hline $\begin{array}{l}\text { Sponsor of the sporting event imparts aesthetic overall appearance for } \\
\text { stadiums }\end{array}$ & $118,174^{\mathrm{a}}$ & 0,000 & + \\
\hline I already changed my mind about a brand after its sports sponsorship & $96,203^{\mathrm{a}}$ & 0,000 & + \\
\hline I trust more in the brand that sponsored the sporting events & $112,406^{\mathrm{a}}$ & 0,000 & + \\
\hline I search for the various offers made by the sponsor of the event & $129,536^{\mathrm{a}}$ & 0,000 & + \\
\hline $\begin{array}{l}\text { I prefer to deal with the sponsor's brand of the sporting event rather } \\
\text { than their competitors }\end{array}$ & $176,319^{\mathrm{a}}$ & 0,000 & + \\
\hline $\begin{array}{l}\text { I will ask via internet to be a member of the sporting event sponsor } \\
\text { online club }\end{array}$ & $342,232^{\mathrm{a}}$ & 0,000 & + \\
\hline $\begin{array}{l}\text { My consumption of the sponsors' products does not relate to their } \\
\text { sporting event }\end{array}$ & $115,884^{\mathrm{a}}$ & , 000 & + \\
\hline
\end{tabular}


Source: prepared by researchers depending on the results of the statistical analysis

Test the second hypothesis: "There is no significant impact at the $0,05 \geq \alpha$ level of significance of sport sponsorship on the image of the sport brand that sponsor the sporting event". Table (09) reveals that the values of the explanatory dimensions for all functions are significant at the level $0,05 \geq$. Thus, we reject the null hypothesis and accept the alternative hypothesis; there is a significant impact at the $0,05 \geq \alpha$ level of significance of sport sponsorship on the image of the sport brand that sponsor the sporting event.

Table 9. The results of $\chi 2$ test of the second hypothesis

\begin{tabular}{|l|c|c|c|}
\hline \multicolumn{1}{|c|}{ Status } & $\chi^{2}$ & P-value & Accept+/Reject- \\
\hline The sponsor of the sport event helps to improve the sport system & $369,014^{\mathrm{a}}$ & 0,000 & + \\
\hline $\begin{array}{l}\text { Sports sponsorship contributes to successful brand for the sport event } \\
\text { sponsor }\end{array}$ & $\begin{array}{c}243,325 \\
\mathrm{~b}\end{array}$ & 0,000 & + \\
\hline Sponsor of the sport event raises the level of their brand goodwill & $200,504^{\mathrm{c}}$ & 0,000 & + \\
\hline $\begin{array}{l}\text { Sponsor of the sport event contributes to increase the media impact } \\
\text { Sponsor of the sport event contributes to increase the budget of sport } \\
\text { clubs and committees }\end{array}$ & $237,388^{\mathrm{b}}$ & 0,000 & + \\
\hline $\begin{array}{l}\text { Usually I link the image of the sponsor brand with the his sponsored } \\
\text { sport event }\end{array}$ & $220,841^{\mathrm{a}}$ & 0,000 & + \\
\hline $\begin{array}{l}\text { When sport event got loss or scandal, sponsor brand will affected by } \\
\text { this bad image }\end{array}$ & $220,087^{\mathrm{a}}$ & 0,000 & + \\
\hline
\end{tabular}

Source: prepared by researchers depending on the results of the statistical analysis

Test the third hypothesis: "There is no significant impact at the $0,05 \geq \alpha$ level of significance of sport sponsorship on the loyalty for the sport brand that sponsor the sporting event". Table (10) reveals that the values of the explanatory dimensions for all functions are significant at the level $0,05 \geq$. Thus, we reject the null hypothesis and accept the alternative hypothesis; there is a significant impact at the $0,05 \geq \alpha$ level of significance of sport sponsorship on the loyalty for the sport brand that sponsor the sporting event.

Table 10 . The results of $\chi 2$ test of the third hypothesis

\begin{tabular}{|c|c|c|c|}
\hline Status & $\chi^{2}$ & P-value & Accept+/Reject- \\
\hline I will affirmatively talk about the brand of the sponsor of sport event & $144,580^{\mathrm{a}}$ & 0,000 & + \\
\hline $\begin{array}{l}\text { I have strong confidence in dealing with the services of the sponsor of } \\
\text { the sports events }\end{array}$ & $168,203^{\mathrm{a}}$ & 0,000 & + \\
\hline $\begin{array}{l}\text { I have perfect satisfaction about the brand of the sponsor of the sport } \\
\text { event }\end{array}$ & $152,609^{\mathrm{a}}$ & 0,000 & + \\
\hline $\begin{array}{l}\text { I am looking for the product of the institutions that sponsored the sport } \\
\text { events }\end{array}$ & $156,406^{\mathrm{a}}$ & 0,000 & + \\
\hline $\begin{array}{l}\text { I am trying to solve the problems that face me in my dealings with the } \\
\text { sponsor of the sport events }\end{array}$ & $311,536^{\mathrm{a}}$ & 0,000 & + \\
\hline
\end{tabular}

Source: prepared by researchers depending on the results of the statistical analysis 


\section{Conclusion}

Sponsorship system is very close to the advertisement without being part of it; it has many forms that are mainly related to pay the sponsoring institution to participate in a special event which is usually a sporting event. On the other hand, the institution gets the rights to advertising within the sports event or a sports facility which is the main reason that attract the institutions to use the sponsorship system, especially if the sport events broadcasted by TV. For example, cigarettes advertisings are not allowed to broadcast some countries television. Thus, the sponsorship system is the best way resorted by the institutions to show its brands on television and sometimes the names of its subsidiaries.

In addition, we found that sports sponsorship in Algeria has received increasing attention by economic institutions and this what proved by studies in the field of marketing on the efficacy of this approach (sports sponsorship) in achieving the objectives at the level of the image, reputation, and direct purchasing and consumption behavior. Finally, could the economic institutions realize this form of sponsorship in order to guide the marketing communication activity in a modern way that makes sport as a tool to reach the achievement of marketing and communication goals?.

\section{References}

Aaker, D. A. (1996). Building strong brands: Building, measuring, and managing brand equity. New York :The Free Press.

Bal, C., Quester, P., \& Plewa, C. (2008). Measuring the influence of emotions on attitude toward sponsors. In Australia and New Zealand Marketing Academy Conference : Sydney, NSW).

Biscaia, R., Correia, A., Rosado, A. F., Ross, S. D., \& Maroco, J. (2013). Sport sponsorship: the relationship between team loyalty, sponsorship awareness, attitude toward the sponsor, and purchase intentions. Journal of Sport Management, 27(4), 288-302.

Cornwell, T. B., Roy, D. P., \& Roy, D. P. (2001). Exploring managers' perceptions of the impact of sponsorship on brand equity. Journal of Advertising, 30(2), 41-51.

Donlan, L. (2014). An empirical assessment of factors affecting the brand-building effectiveness of sponsorship. Sport, Business and Management: An International Journal, $4(1), 6-25$.

Irwin, R. L., Lachowetz, T., Cornwell, T. B., \& Clark, J. S. (2003). Cause-related sport sponsorship: an assessment of spectator beliefs, attitudes, and behavioral intentions. Sport Marketing Quarterly, 12(3), 131-139.

Johansson, M., \& Utterström, T. (2007). Sport sponsorship: a marketing communication tool in Swedish companies. Master thesis in marketing, Lulea university of technology, Sweden.

Keller, K. L. (1993). Conceptualizing, measuring, and managing customer-based brand equity. The Journal of Marketing, 1-22. 
Kim, J. W. (2010). The worth of sport event sponsorship: an event study. Journal of Management and Marketing Research, 5(1), 1-14.

Lassar, W., Mittal, B., \& Sharma, A. (1995). Measuring customer-based brand equity. Journal of consumer marketing, 12(4), 11-19.

McDaniel, S. R. (1999). An investigation of match - up effects in sport sponsorship advertising: The implications of consumer advertising schemas. Psychology \& Marketing, 16(2), 163-184.

Motameni, R., \& Shahrokhi, M. (1998). Brand equity valuation : a global perspective, The Journal of Product \& Brand Management,7(4), 275-290.

Pijkeren, J. (2010). Strategic value of networking in sport sponsorships. Master thesis, University of Twente - Enschede-The Netherlands

Reiser, M. Breuer, C., \& Wicker, P. (2012). The sponsorship effect: Do sport sponsorship announcements impact the firm value of sponsoring firms? International Journal of Sport Finance, 7, 232-248.

Sandler, D. M., \& Shani, D. (1989). Olympic Sponsorship Vs Ambush Marketing-Who Gets The Gold. Journal of advertising research, 29(4), 9-14.

Shalabi, S. A. (2005). The fondations of sports marketing department, Modern library, Mansoura, Egypt, 151-165.

Siddiq, W. M (2011). the type of care impact on consumers' purchasing trends, a letter of introduction to get a Master's degree in Business Administration, Faculty of Commerce, Ain Shams University.

Simon, C. J., \& Sullivan, M. W. (1993). The measurement and determinants of brand equity: a financial approach. Marketing science, 12(1), 28-52.

Sponsorship report (2013), IEG

http://www.sponsorship.com/iegsr/2015/01/07/2015-Sponsorship-Outlook--Spending-Increas e-Is-Dou.aspx (02/05/2015)

Tripodi, J. A. (2001). Sponsorship-a Confirmed Weapon in the Promotional Armoury.(Analysis). International Journal of Sports Marketing \& Sponsorship, 3(1), 95.

Weissman, M. (2014). Sports Sponsorship: Fan Loyalty And Perception Of The Lake County Captains Minor League Baseball Team. Marketing.

\section{Copyright Disclaimer}

Copyright for this article is retained by the author(s), with first publication rights granted to the journal.

This is an open-access article distributed under the terms and conditions of the Creative Commons Attribution license (http://creativecommons.org/licenses/by/3.0/). 